\title{
FEATURES OF USING MOOC RESOURCES IN ENGLISH LANGUAGE TEACHING
}

\author{
Zhanbyrbay Kagazbayev', Nazym Tokpayeva ${ }^{2}$ \\ ${ }^{1}$ E.A. Buketov Karaganda University, Karaganda, Kazakhstan \\ ${ }^{2}$ E.A. Buketov Karaganda University, Karaganda, Kazakhstan
}

ORCID iD: 0000-0002-2090-0132

\begin{abstract}
Massive Open Online Course (MOOC) is part of the big invention of technology in education nowadays. With the existence of technology in today's world, technology currently acts a big role and invention in the 21st century teaching and learning. Massive Open Online Course (MOOC) is widely known by most universities all over the world. Most universities have started to implement the combination of MOOC and traditional classroom as part of the teaching and learning process especially in ESL learning. In Kazakhstan, English language is well-known for its role as the second language and English language is not only used in the primary and secondary level of education, but also in tertiary level of education. Thus, in relation to that, this paper intended to study students' acceptance and perceptions on the use of Massive Open Online Course (MOOC) for ESL learning. A document analysis method is used through the secondary resources regarding MOOC and in what ways MOOC helps for ESL learning. Discussion and recommendations are further explained in this study.
\end{abstract}

\section{INTRODUCTION}

Online learning is the new innovation used for education and MOOC plays the leading role in this area. Technology and students are inseparable in today's world [Alexandrov, 2012; Arsova, 2021; Arsova, 2020; Goletiani et al, 2021; Petrova \& Aleksandrov, 2018; Sushchenko et al, 2021]. In an online environment, students will be able to communicate and interact with others at their own pace and take time to consider comments and responses. Students tend to have more time to think and brainstorm ideas for certain topic discussions given by the teacher.

Students also prefer technology as part of their learning as it is more handy for the students to access the information using technology wherever and whenever they want. Advantages of using ICT and technology in learning and teaching session were reported to be beneficial in attracting students' attention, facilitating students' learning process, helping to improve students' vocabulary and also promoting meaningful learning to students [Abeer, Miri, 2014]. With the existence of technology and ICT and the rapid use of it in teaching and learning process, MOOC that stands for massive open online course is a web-based course available for free to any participant from all around the world [Anzai, Akahori, 2015] started to arise. MOOC provides free access to high-quality learning materials, offered by elite universities and they are conceptualised as online learning environments in which participants worldwide can create, research and share open educational resources [Anzai, Akahori, 2015].

Massive Open Online Courses or widely known as MOOC has now gained its name all around the world among the top universities. MOOC has become one of the most current and recent innovations in today's education. MOOC is the combination of online course, interactivity and mutual but virtual communication [Ejreaw, Drus, 2017]. MOOC basically allows students to 
evaluate, discuss and even interact with each other as MOOC is a mixture learning with the combination of teachers, students, videos, tests, communication and other related ICT tools. Universiti Kazakhstan (UKM) is known for its massive routine of using MOOC as part of its teaching and learning process. The style of blended learning is practiced in UKM with the combination of traditional classroom along with the use of MOOC to further enhanced students' development and understanding.

In relation to ESL learning, MOOC in some sense provides ESL learners the opportunity to 'study abroad' [Ejreaw, Drus, 2017]. Most leading universities in the world use MOOC as part of their teaching and learning process, including Kazakhstan, Universiti Kebangsaan Kazakhstan (UKM) also has its lecturers and staffs to conduct majority of their courses through online courses.

MOOC is said to be able to help students especially undergraduate students in their ESL learning without them realising it. In this situation, students might have overlooked the importance of MOOC in their ESL learning and how MOOC indirectly helps them in their English language acquisition. As the growth use of MOOC is increasing rapidly in today's world of education, there are quite a number of literatures related to the use and benefit of MOOC in teaching and learning all around the world. However, there are no clear distinction on students' acceptance on the use of MOOC for ESL learning provided by past researches. The use of MOOC as part of the teaching and learning session is hoped to be able to help university students with their ESL learning.

\section{METHODOLOGY}

This paper is using the document analysis method to analyse students' acceptance and perceptions on the use of Massive Open Online Course (MOOC) for ESL learning. Content analysis is used through secondary research. The secondary research data was gathered by eighteen literatures reading from written publications related to the issue of MOOC generally and the intervention of MOOC for ESL learning.

\section{RESULTS AND DISCUSSION}

\section{The development of MOOC for ESL learning}

Massive open online course or also known as MOOC is a webbased course available for free to any participant from any place in the world [2]. MOOC is conceptualised as online learning environments in which participants all around the globe are able to share educational resources and at the same time interact with each other. MOOC is used in most of the elite universities around the world. [Ejreaw \& Drus, 2017] in her study mentioned that more than 73 universities use the combination of traditional classroom with advanced MOOC as their styles of education and the use of MOOC has increased from the year 2021 with more than 400 universities all around the world have acknowledged and started to use MOOC.

[Ulrich \& Nedelcu. 2015] mentioned that the year of 2012 is 'the year of MOOC' According to The New York Times, MOOC is considered as convenient as MOOC learning style is quite flexible and learners can use various devices such as laptops or even perhaps using their own smartphones to have access to it, so learners, undergraduate students in this situation can have control of their own learning. The Ministry of Education in Kazakhstan has developed three major plans for using ICT in education. [Abeer \& Miri, 2014] stated on their paper on the three measures planned by the Ministry of Education to implement the use of ICT in Kazakhstan's education. One of the plans is to make use of ICT as a teaching and learning tool and relating MOOC to ESL learning, it is figured that ICT were able to encourage ESL learners' independence and self-discovery skills especially in writing 
skills. The findings are in relation to this study as this study aims to investigate in what ways MOOC helps undergraduate students for their ESL learning.

In another previous study done by [Anzai \& Akahori, 2015] which has developed an online language learning tools using MOOC considering learners would be motivated to participate and improve their knowledge, lead to a finding of $59 \%$ of the respondents were the learners of ESL learning. Their findings were aligned with the suggestion of MOOC does have impact towards ESL learners in their ESL learning as MOOC has been proven suitable to be used for language teaching and learning. [6] has discovered in their study that MOOC is to be said as the window for learners to train themselves with the sense of openness, self-efficacy and willingness to communicate. MOOC influences students' openness in general and provides them with positive attitudes towards English language. Openness resulted to improving students' ESL proficiency and MOOC can be one of the mediums for students' English language acquisition.

MOOC motivates students to interact with one another. A lesson in MOOC might need students to introduce themselves using perhaps a video or a paragraph of introduction in English language. Not to mention, there are rare occasions happening of the lesson of MOOC to being conducted in other languages other than English. Thus, with English language is to be considered as the dominant language in MOOC, the interactions and sharing knowledge with each other even with the tutor or teacher despite the language barrier might help students somehow to be more open to new knowledge and to be more willing to communicate and interact in English language. MOOC's ability to supply a social platform for students to interact with one another among the participants managed to provide positive support for students to take charge of their own learning especially in ESL learning. The ability of students to work collaboratively in MOOC makes them to be able to set their own goals, developed new knowledge, improved their language skills and even built their selfconfidence. The more frequent and autonomously students to be able to engage with the target language, it will give them more chances to acquire the language on their own [Wu, Fitzgerald, Witten, 2014].

\section{Learning theories research on MOOC}

There are quite a number of learning theories research related to MOOC based on previous studies. Literatures provided a variety of theories that different researchers used to further support their studies on MOOC. One of the theories used in this study is the sociocultural theory which emphasises on the construction of cognitive schemes by individuals through interactions and communication. This theory is appraised to be one of the important theories relating to this study because social communications and social interactions help to build meaningful learning. In relations of MOOC for ESL learning, meaningful learning is needed for students to be able to acquire the language and develop their English language proficiency skills. MOOC is considered to be one of the mediums or platforms for students to build meaningful learning as virtual interactions and communications do happen in MOOC. Potentially, participants of MOOC are able to work collaboratively in many activities provided in the MOOC prepared despite the language barrier. It is argued that not all MOOC provide students with the activity of teamwork and collaboration that might help them in their ESL learning, however, regardless of that, through the content of meaningful learning provided by MOOC, students tend to learn from each other; in a sense of other students' language, style of writing and even the use of vocabulary through the sharing of knowledge and information from the tasks given in MOOC.

On another note, MOOC is also related to the theory of connectivism by many scholars. The theory of connectivism is the learning theory that explains how technology created new chances and opportunities for people to learn. However, according to a study, they mentioned on the relation of 
connectivism theory with MOOC is somehow argued on how they think that the theory did not provide enough explanation to learning phenomena because the theory is assumed to neglect other important aspects of learning. In relation to this study, this theory is not as significant as the other theory mentioned above as this study seeks to find out the relation of MOOC with language learning, not the impact of MOOC as the medium of learning alone.

\section{The use of Massive Open Online Course (MOOC) for ESL learning}

Students' acceptance is considered to be the in a way whether students accept the use of MOOC as part of their learning process at university. Students' acceptance is to determine whether students fond of the use of MOOC or the other way around. On the other hand, students' perception in this study is defined as students' opinions on the use of MOOC especially in ESL learning. Both good and bad opinions are considered to be perceptions in investigating the use of MOOC in ESL learning.

Students' acceptance and perceptions towards MOOC may vary depending on their take on MOOC whether MOOC does help them in their ESL learning and in what ways can MOOC helps them improving their English language acquisition. In related past research, they figured out various factors that might contribute to different perceptions and acceptance among students when it comes to MOOC. Their study resulted to the indications of five learning competencies that might affect students' participation in MOOC. Among them are linguistic competence in English, selfefficacy and communication skills.

Students with low proficiency of English language might have trouble to cope with MOOC as English language is to be considered as the dominant language in MOOC. There are possibilities that they might have issues in communicating and interacting with other participants in MOOC as they get intimidated with other people's level of proficiency in English language. The idea of interacting in English language scares them but with practice and the actions are to be applied frequently eventually will help students to get familiar with English language. Obviously, students' self-discipline plays a big role in determining the impact of MOOC especially in relation to ESL learning.

In another study which investigated the impact of integrating MOOC in an English language classroom, it is found through the findings that MOOC in a way helps students to enhance their writing and grammar skills. MOOC is claimed to be as an enjoyable learning and allows for grammar improvement for students through the tasks prepared. [Ejreaw, Drus, 2017] also has the same opinion on that the most crucial way of learning English is to make students to get involved in the English environment. [Ejreaw, Drus, 2017] also mentioned in their study that MOOC can be expected to be useful in English language learning. This is parallel to the findings in a study done by on her survey has resulted to the findings of how students are able to improve their grammar, writing skills and even vocabulary through collaborative learning and interactions.

The intervention and integration of Information and Communication (ICT) in education has provided more variety in the process of teaching and learning especially involving tertiary level of education where learners get to be more interactive and participative during the learning session. In a study done, it is stated that it is very crucial for tutors to consider learners' level of acceptance and their perceptions on the use of MOOC during teaching and learning session as for example, it can be in collaborative learning, learners might somewhat be forced to collaborate among one another. Eventually, the language learning acquisition is not happening. Further insight on this issue would be beneficial for MOOC development. 
MOOC as an independent learning platform is expected to help learners with the practice of self-centred learning especially in language learning through the feedbacks and discussion platform and this has attracted many academicians all over the world to have MOOC as part of their teaching and learning process. However, in a study of student retention in MOOC, MOOC is usually used more as aided learning in some universities of institutions because face-to-face or conventional learning still plays the major role and MOOC is used for blended learning which leads to maintaining interaction with learners becoming challenging and some learners might not even participate in the discussion platform prepared in MOOC. Thus, it can be seen that the learners' acceptance and perceptions of MOOC might vary depending on their style of learning and their own effort to acquire and improve their ESL learning acquisition.

\section{CONCLUSION}

Despite the lack of literatures of MOOC in relation to ESL learning specifically, based from the past literatures on MOOC, it can be concluded that even MOOC in general provides a solid platform for students to gain meaningful learning with content that in a way indirectly helps them to improve their English language learning even without them realising it and it is no longer questionable how MOOC has been proven to be able to provide all these catalysts for students to improve their ESL learning. It is proven that this study would be fruitful for all parties related to the ESL learning study.

\section{REFERENCES}

Abeer W, Miri B. (2014) Students' preferences and views about learning in a MOOC. Procedia-Social and Behavioral Sciences.

Alexandrov M.O. (2012). One Approach for the Realization of an Online Poker Game - Funpoker. Proceedings of IX International scientific conference "Science and Education", Kemerovo State University, Belovo Institute (branch), March 28-29, 2012, Belovo, Russia. Vol.1., pp. 124-127

Anzai Y, Akahori K. (2015) Openness, Self-efficacy, and Willingness to Communicate in a MOOC Learning Environment. InAnnual Proceedings of Selected Research and Development Papers Presented at the Annual Convention of the Association for Educational Communications and Technology (38th, Indianapolis, Indiana)

Arsova, D. (2021). Skills and competencies of the new generation of students to work with digital devices // "Innovations in technology and education": proceedings of XIV International scientific conference "Innovations in technology and education", 26 march 2021 г.: Kuzbass State Technical University, Belovo, Russia; 2021. - vol. 3., pp. 59-66

Arsova, D. (2020). Developing of the elementary school students'skills in a digital world // "Innovations in technology and education": proceedings of XIII International scientific conference "Innovations in technology and education", 26 march 2020 г.: Kuzbass State Technical University, Belovo, Russia; 2020. - vol. 4., pp. 55-60. ISBN 978-5-00137-065-9

Bakar NA, Latif H. (2010) ESL Students feedback on the use of blogs for language learning. 3L: Language, Linguistics, Literature®.

Chai Y., Yang L.S. (2014) A Literature Review of MOOC. In Proceedings of 3rd International Conference on Science and Social Research (ICSSR 2014). Atlantis Press

Ejreaw A, Drus M. (2017) The challenges of massive open online courses (mooc)-a preliminary review. ICOCI Kuala Lumpur. Univ. Utara Kazakhstan. 
Goletiani, K., Mushkudiani, Z., Gulua, E., Janelidze, N. (2021). Difficulties in managing diversity in Georgian educational organizations. Access to science, business, innovation in digital economy, ACCESS Press, 2(2): 123-137. https://doi.org/10.46656/access.2021.2.2(1)

Johnson L, Becker SA. Enter the anti-MOOCs. Massive Open Online Courses: The MOOC Revolution. 2014 Nov 20:61.

Liu D. (2016) The reform and innovation of English course: A coherent whole of MOOC, flipped classroom and ESP. Procedia-Social and Behavioral Sciences.

Petrova, M., Aleksandrov, M. (2018). Automating the virtual hosts maintenance in a multi-site environment. International Congress on Business and Marketing (ICBM'18), Marmara Eğitim Köyü Maltepe / İstanbul, TÜRKIYYE, Proceedings of the International Congress on Business and Marketing, 2018 Maltepe University, Istanbul, ISBN 978-605-2124-09-03, p.392-404

Sushchenko, O., Akhmedova, O., Stryzhak, O. (2021). The use of interactive training technologies in teaching academic disciplines for students of tourism specialities. Access to science, business, innovation in digital economy, ACCESS Press, 2(1): 28-39. https://doi.org/10.46656/access.2021.2.1(3)

Ulrich C, Nedelcu A. (2015) Moocs in our university: Hopes and worries. Procedia-Social and Behavioral Sciences.

Wu S, Fitzgerald A, Witten I.H. (2014) Second language learning in the context of MOOCs. InCSEDU (Vol. 1, pp. 354-359). SCITEPRESS.

Yunus M.M., Nordin N., Salehi H., Embi M.A., Salehi Z. (2013) The use of information and communication technology (ICT) in teaching ESL writing skills. English Language Teaching 